\title{
Niche or Mass Market? The Regional \\ Context of Tourism in Palau
}

Lonny Carlile

$\mathrm{Pa}$ assistance from Washington that had come to play a central role in its assistance from Washington that had come to play a central role in its economy, Palau, which gained independence in October 1994, is faced with the daunting task of building a self-sustaining national economy in a turbulent and rapidly globalizing world. This tiny Pacific Island country has few natural resources to exploit and is unlikely to duplicate the manufacturing-based, export-led growth strategy of the so-called East Asian model. As in other small island nations, international tourism is currently being touted as the viable industry for the country, and this in turn has precipitated debate over the merits of tourism-based development.

International tourism development is often discussed as if it were akin to selling a commodity in a centralized global exchange-offer the "product" on the "market" and customers will "buy" according to the principles of supply and demand. While such a characterization might be valid at a highly aggregated, abstract level over the long run, the practical reality of national tourism development is one in which, to use the language of neoclassical economics, a variety of "externalities" "distort" the market and structure the opportunities available to countries in very significant ways. This is fundamentally true of small island nations like Palau that depend on air transport as the primary medium for conveying inbound tourists. Under the current international air transport regime, outcomes are as much a product of the highly political process of interstate negotiations as they are of market forces. Tourism flows are also affected by such factors as the degree and character of sovereignty possessed by a state, the idiosyncrasies of diplomatic relations, and the economic policies pursued by states exporting and importing tourists. All of these shape the flow of tourists and tourism development funds across

The Contemporary Pacific, Volume I2, Number 2, Fall 2000, 4I5-436

(C) 2000 by University of Hawai'i Press 
national boundaries. What is commonly referred to as the economics of international tourism is more correctly understood as a political economy of interstate tourism development. In weighing options and developing strategies for tourism development in Palau, it is important to recognize the structural features of the political economy of interstate tourism at work.

This paper analyzes the political economy of tourism development in Palau from a regional and historical perspective. It begins with a general discussion of the larger context of the development of international tourism in the Asia-Pacific region. As detailed in that section, in recent decades Asia-Pacific tourism has in large part been the story of the expansion of Japanese overseas tourism, with its distinctive set of modalities and geopolitics, followed more recently by the emergence, on a much smaller scale, of the overseas tourism of the East Asian newly industrializing economies. The next section outlines the regional context of tourism development in Palau and reviews how tourism and tourism development have unfolded in Micronesia since the late I960s. I argue that the distinctive contours of political status in the region interacted with the development pattern of Japanese overseas tourism to produce a distinctive geography of tourism and tourism development in the region surrounding Palau. This regional context frames the next section, which focuses on Palau's experience with tourism. The concluding section outlines some implications.

\section{Patterns of Overseas Tourism in Asia and the Pacific}

Japan is currently the dominant source of tourists visiting Micronesia, although in the last decade or so there has been significant growth in the number of tourists from South Korea and Taiwan (table I). The dominance of Japanese tourism and the recent emergence of Taiwanese and South Korean overseas tourism are not unique to the Micronesian region, but reflect a general trend in the evolution of the global tourism industry over the last three decades. The rapid growth in the number of Japanese overseas travelers as that country attained "economic superpower" status has been one of the most significant global trends in international tourism. Historically, the number of Japanese overseas travelers, most of whom are tourists, began to exhibit a secular growth pattern following the loosening of controls on foreign exchange and external travel in 1964. Not until eight years later, in 1972, however, did the total number exceed one million, a figure that doubled the next year. Japanese overseas travel contin- 
ued to grow at an exponential rate thereafter, thanks to impressive economic growth, further foreign exchange liberalization, rapid appreciation of the yen, and the rapid increase in the number of airline seats worldwide associated with the introduction of wide-body jets (figure I). As a consequence of this growth, and stagnant growth in inbound tourism, Japan has emerged as the world's largest net exporter of tourist dollars.

The growth pattern encouraged a distinctive organizational format in the business of servicing Japanese tourists (Carlile 1996). This format appears to have been duplicated in the Taiwanese and South Korean overseas tourism industries, although this has not been studied systematically. Rapid growth from a minuscule base meant that neither existing foreign travel firms nor tourist facilities at overseas destinations were adequately prepared to service the burgeoning numbers of Japanese tourists. Japanese firms saw an opportunity to establish a solid foothold in the market by offering travel services-eg, predeparture briefings, reservations, tour escorts, Japanese-language assistance, cultural sensitivity to Japanese predilections - that could not be effectively provided by foreign firms at the time. Furthermore, because until the I980s Japanese income levels were lower than those of most industrialized countries, there was great pressure to keep costs and prices down. The low-cost package tour created out of massive bulk prepurchases of airline seats, hotel room reservations, and other services quickly became the dominant mode of overseas travel and

Table I. Visitor Arrivals in Micronesia and Hawai'i

\begin{tabular}{|c|c|c|c|c|c|c|c|c|}
\hline & \multicolumn{2}{|c|}{$\begin{array}{l}\text { Palau } \\
\text { (I997) }\end{array}$} & \multicolumn{2}{|c|}{$\begin{array}{c}\text { Northern } \\
\text { Marianas } \\
(\text { I996) }\end{array}$} & \multicolumn{2}{|l|}{$\begin{array}{l}\text { Guam } \\
\text { (1997) }\end{array}$} & \multicolumn{2}{|c|}{$\begin{array}{l}\text { Hawai'i } \\
(\text { I995) }\end{array}$} \\
\hline & No & $\%$ & No & $\%$ & No & $\%$ & No & $\%$ \\
\hline Japan & 20,507 & 28 & 438,462 & 60 & $1,113,012$ & 81 & $1,998,860$ & 30 \\
\hline South Korea & 1,782 & 2 & 187,881 & 26 & 119,118 & 9 & 104,550 & 2 \\
\hline Taiwan & 31,246 & 42 & 6,077 & 1 & 22,453 & 2 & 62,750 & 1 \\
\hline Other & 20,184 & 27 & 103,697 & 14 & 118,627 & 9 & $4,463,020$ & 67 \\
\hline Total & 73,719 & & 736,117 & & $1,373,210$ & & $6,629,180$ & \\
\hline
\end{tabular}

Sources: Guam Visitors Bureau; CNMI Visitors Bureau; Palau Visitors Authority. 
gave Japanese overseas tourism a decidedly "mass" quality. Although such practices are hardly unique to the East Asian travel industry, the need to keep the price of tour packages low encouraged the extensive use of kickbacks and commissions at tour destinations (ie, payments to tour operators and escorts bringing tourists to a local business or attraction) to make up for limited revenue at the tour package's point of sale.

Mass tourism based on prepackaged tours has encouraged a hierarchical oligopolization of the industry. The top five Japanese travel agencies, all of whom engage in bulk packaging of outbound tours, have been estimated to control about two-thirds of the outbound travel market (Nozawa I992, 229). The large capital resources of these mega-agencies give them the ability to buy huge quantities of airline seats, hotel rooms, and various other services from suppliers at highly discounted rates, usually via contracts negotiated semiannually. In turn, this ability has structured the industry in a particular way. First, the system has encouraged the participation of the largest travel agencies in the leading overseas travel destinations. Needless to say, bulk purchasing works best where the "raw materials" of travel packages are available in bulk, and precisely for this reason mainstream Japanese overseas tourism has been heavily oriented toward tour destinations with large hotel developments well-

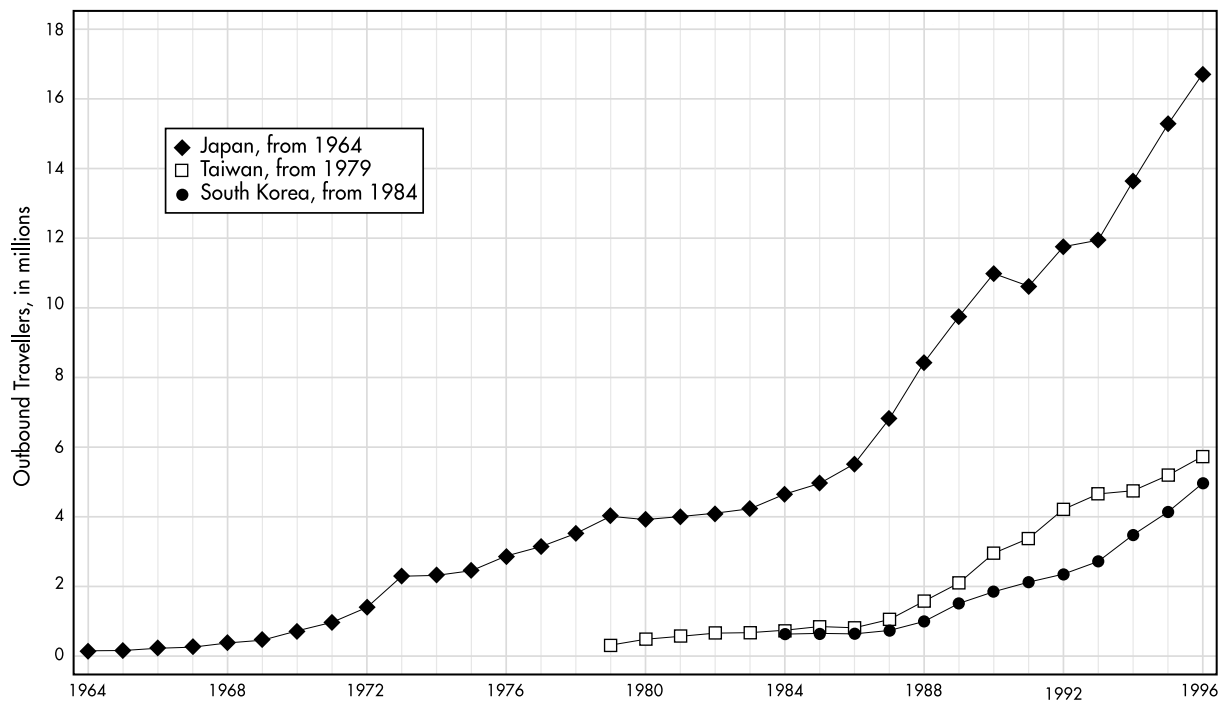

Figure I. Total numbers of overseas travelers from selected East Asian countries. (Sources: Travel Journal I994, 229-230; http://www.jnto.go.jp/I 2jntowho/ I 2 frame.html; Huang, Yung, and Huang 1996, 224; http://www.apot.com/ groindex.html; Korea Statistical Yearbook 1994, 60; 1997, 80.) 
serviced by major airlines. Second, the system has encouraged vertical integration. Wholesalers purchase tour package "parts" (eg, airline seats, hotel rooms, tickets to tourist attractions) well beyond what they need for their own clients, both to reduce unit costs (other things being equal, the larger the purchases, the larger the discounts and commissions received from suppliers) and to assure access to choice seats and rooms for their clients during the profitable peak seasons. The excess is resold to smaller travel agencies and discount brokers for sale in secondary markets. As a result, on the retail side of the Japanese travel industry, numerous smaller retail agencies maintain an "affiliation" (also known as a keiretsu tie) with the larger firms that supply them with "parts" and packages (Isozaki I993; Travel Journal 1994, 53-54; Kojima I995, 32-33, 47-49). Third, despite the tendency toward vertical integration, opportunities do exist for smaller, specialized travel firms. For instance, given their higher personnel and organizational costs and orientation toward large-scale transactions, it is simply not worth the effort for the major wholesalers to directly service smaller destinations. Small, "niche" wholesalers have emerged, who can provide discounted parts and packages to larger firms in less popular destinations.

A fourth feature of the system, and one that also represents a limit on the tendency toward vertical integration, can be seen in the continuing control maintained by foreign suppliers over key "parts." Other things being equal, the logic of vertical integration should be just as compelling in the "upstream" direction as in the "downstream" direction, as is suggested by the existence of wholesalers who are affiliates or subsidiaries of airline companies (notably, JALPAK [associated with Japan Airlines], All Nippon Airways World, Japan Air Systems Enterprises) and certain hotel chains that have affiliations with airlines and large travel agencies (eg, Japan Airlines' Nikko chain, Tokyu's Pan-Pacific chain, Japan Travel Bureau's association with Intercontinental Hotels). Nevertheless, complete upstream integration of the Japanese overseas travel industry has been hampered historically for a number of reasons. Because the industry was oriented toward the world's major tourist destinations, it was confronted in such destinations with preexisting, well-established foreign hotels and hotel chains (Travel Journal 1994, 224-227). As developments in Hawai'i and other destinations indicate, Japanese interests were still capable of taking over properties and building new ones, but the strength of existing American and European hotel chains meant that oligopolization by Japanese interests would necessarily be incomplete. The same situation existed with respect to the airlines. International airline services in the 
post-World War II period continue to be based on a web of bilaterally negotiated agreements in which governments in effect offer foreign carrier access to domestic "gateways" in exchange for reciprocal access for their own national carriers to their negotiating partner's gateways. Such a system encourages a bilateral division of traffic between two countries, thereby hampering the development of unilateral monopolistic or oligopolistic control by a single nation's carriers over a given air route. As I discuss in more detail later, in the Japanese case, a distinctive stipulation in that country's bilateral aviation treaty signed with the United States in I952 effectively locked in an existing US carrier dominance over air access to and from Japan (LaCroix and Wolf I995; Yamauchi and Ito I996; Jaggi and Morgan I996).

As for South Korean and Taiwanese overseas tourism, elements of the Japanese pattern have been unfolding with a fifteen- to twenty-five-year lag. Taiwan began liberalizing overseas travel regulations in 1979. As of I990, embarkation and disembarkation forms were no longer required of residents, and the amount of foreign exchange that could be taken out of the country was increased to us\$5 million per year (Huang, Yung, and Huang I996, 224). South Korea followed suit by liberalizing its overseas travel procedures and foreign exchange controls in 1989 (Korea Travel News 1989). These liberalizations were followed by dramatic increases in the number of overseas travelers from the two countries. Personnel able to speak the languages and sensitive to the customs of these countries were in short supply at overseas destinations (Ahmed and Chon I994). In both instances low-cost package tours sold by domestically based travel agencies have come to serve as the primary mode of overseas travel. It is unclear at this point whether or not the Asian financial crisis that began in 1997 will alter this pattern. In any event, given the smaller population bases of the two countries it is unlikely that either will generate an overseas tourist population that exceeds the Japanese in size.

\section{The Political Economy of Interstate Tourism Development in Micronesia}

Micronesia's trust territory status meant that air transport within the territory was regulated by the domestic aviation regime of the United States, while foreign access to the region was governed by the provisions of aviation treaties negotiated by the United States with foreign governments. Under the original provisions of the 1952 US-Japan treaty, access to the 
United States by Japan's international carriers was restricted to the five designated "gateways" of Guam, Saipan, Honolulu, Anchorage, San Francisco, and New York, while US access to Japan was restricted to the gateways of Tokyo and Osaka. Naha was added to the list when Okinawa reverted to Japan in 1972. (Each country was free to choose other points of origin within their respective countries.) Carrier service between the two countries was effectively limited to four designated "incumbent" airlines-Japan Airlines (JAL) on the Japanese side, and Pan American (PanAm), Northwest, and the cargo carrier Flying Tiger on the American. While carriers from both countries were in theory free to increase or reduce capacity on their designated routes at will, in practice the overcrowded conditions at the Tokyo and Osaka airports meant that the Japanese Ministry of Transportation was in a position to regulate capacity through its control over the allocation of "slots" (takeoff and landing permits) at these airports. Any significant changes to this bilateral regime thus had to be attained through agreements ironed out in bilateral negotiations (Yamauchi and Ito I996, 47-49; LaCroix and Wolf I995).

Exclusive right to provide "domestic" service within the Trust Territory and between parts of the territory and the United States was originally granted to PanAm. However, since PanAm was at the time the premier American international carrier, it did not put a high priority on its Micronesian operations and there were incessant complaints about its poor service. PanAm's rights in the region were subsequently transferred to the Continental Airlines-affiliated Air Micronesia (later renamed Continental Micronesia) on a temporary basis in 1968. The airline was permanently certified on these routes in I97 I. Under the mandate granted to Continental, in addition to providing air service to the region, the company was committed to promoting tourism development and the training and recruitment of local personnel in the travel industry. In response to these provisions, Continental built a chain of "Continental" hotels in three district centers in the Trust Territory (Kelley and Penseyres I976, 8).

The combination of the US-Japan aviation treaty and the intraregional arrangements centered around Air Micronesia had a number of implications for tourism development in the region. Perhaps most obvious, the designation of Guam and Saipan as gateways virtually guaranteed that increases in traffic from Japan would tend to concentrate at these two destinations. PanAm initiated direct flights between Tokyo and Guam in 1967, and Japan Airlines followed suit in I970, opening the way for Guam's emergence as a popular honeymoon destination for Japanese 
newlyweds. Beyond these developments, little incentive existed for the two airlines to promote Micronesian destinations outside Guam and Saipan since access to these destinations was controlled by Air Micronesia.

From Continental's perspective, on the other hand, there was a strong commercial incentive to try to extend its pan-Pacific reach (achieved through Air Micronesia's Trust Territory connections) by adding a route that would connect its Micronesia network with Japan. Doing so would not only offer the prospect of turning the chronically unprofitable Air Micronesia around through the added passenger load, but would also provide a new source of guests for its hotels in the region. Domestic and international politics, however, frustrated Continental's bid. An agreement authorizing the initiation of service between Saipan and Tokyo, which Continental wanted, had been reached in bilateral negotiations in I969 and Japan Airlines began flights the following year. An upgrading of the Saipan airport to allow the landing of wide-body jets was begun around this time. On the US side, however, fierce jockeying between PanAm and Continental delayed the designation of a US carrier for the route. Civil Aeronautics Board hearings on carrier designation were not initiated until I97I. The infighting continued, and it was not until August I976 that President Gerald Ford finally approved Air Micronesia's designation as the US carrier for the Saipan-Japan route (Davies I984, 59-64).

Unfortunately for Air Micronesia, additional hurdles had to be overcome. The Japanese feeling that unfair advantages had been given to the United States in the 1952 aviation treaty intensified as the number of Japanese passengers began to exceed those from the United States and the margin widened. Dissatisfaction built up to the point that the Japanese government was induced to initiate a full-fledged renegotiation of the treaty. Not surprisingly on its part, the United States was unwilling to entertain a reworking of the treaty's basic principles. Air Micronesia's Saipan-Tokyo service bid became caught up in the resulting deadlock as Japanese officials held Air Micronesia's slots in Tokyo hostage for concessions from the United States. A "memorandum of understanding" that authorized Air Micronesia's Tokyo-Saipan route was at last signed in July I977, and service was initiated in October-eight years after the route was initially authorized (PIM, June I977; Doty I977a, I977b).

Air Micronesia's attainment of access to the Japanese market, together with the counterpart expansions of Japan Airlines' service to the region, resulted in an increase in the number of seats available for Japanese tourist travel to Guam and Saipan and also made other Micronesian destinations 
somewhat more accessible to Japanese tourists. However, the resulting increases in capacity paled in comparison to the dramatic increases that followed the wave of liberalization that washed over the international airline industry in the I980s. The impact of this movement was first felt in the Micronesian region when, after the conclusion of a "record of communication" between the United States and Japan in 1982, the city of Nagoya was opened to Air Micronesia and the way was opened for All Nippon Airways (ANA), Japan's second largest airline, to begin operating charter flights between Guam, Saipan, and Tokyo. A new memorandum of understanding in 1985 removed earlier restrictions on Air Micronesia's equipment size and also authorized the airline to add routes linking Guam and Saipan with the additional Japanese cities of Osaka, Fukuoka, and Naha. The same memorandum also authorized the entry of Japanese airlines other than Japan Airlines on Japan-Guam routes, paving the way for All Nippon Airways to open regular service between Tokyo's Narita Airport and Guam in July. A 1989 memorandum of understanding made possible JAL service between Nagoya and Saipan or Guam, ANA service between Narita and Saipan, and Air Micronesia connections to Sendai. The consequences of this wave of airline liberalization are reflected in the relevant statistics. The number of Japanese visitors arriving in Guam grew from roughly I53,000 in 1977 to 222,000 in 1980 . By 1990 , this figure had nearly tripled to 638 ,000 (GVB I998).

In the original Civil Aeronautics Board authorization of Continental's Micronesian entry was the requirement that the company pursue hotel development, on grounds that limited tourism infrastructure was an important obstacle to further expansion of tourism in the region. In the absence of a history of overseas tourism, international tourist-class hotel rooms were nonexistent in most areas of Micronesia. Continental's hotel projects, which at 50 to 200 rooms were small by international standards, were unprecedentedly large by earlier regional standards. Further investment in hotel rooms was unlikely without firm prospects for increased tourist traffic. Although the initial boom in Asia-Pacific tourism spurred by Japanese overseas travelers was promising, the political geography of the region and the difficult diplomacy of airline negotiations provided only modest incentives for hotel development.

Under these circumstances, it was not surprising that Japanese investors took the initiative to develop hotels in Guam for Japanese visitors spurring a steady increase in hotel capacity (figure 2). Given the near absence of preexisting tourist-oriented hotel development, in contrast to major des- 
tinations elsewhere, there were almost no barriers to oligopolization by Japanese tourism-related interests. As a result, the organization of Japanese tourism in Guam came to reflect the quintessential tendencies built into the Japanese travel industry system. By I984, four of the eight resort hotels on Guam were owned by Japanese interests, and two others were managed by Japanese firms. Guam had by this time developed into a sizable destination for Japanese tourists (90 percent of visitors to Guam in I984 were from Japan), so the leading travel agencies had established operations on the island. In addition to lining up families of affiliated tour operators, long-term business ties were established with local restaurants, shops, and tourist attractions. Kickbacks and commissions provided an important way for tour companies to compensate for the low price of tour packages and helped to further solidify the Japan-based network that oligopolized Japanese tourism in Guam. As one observer wrote, "no other tourist destination in the world is so completely locked up by a single source of travelers and investors" (Nygard I984, I I). Expanded air service did little to alter the situation, and as Saipan came into its own as a major site for Japanese tourism in the latter half of the I980s, Guam's experience was duplicated. A survey article in the Guam Business News a decade later concluded, "Almost all of the 549,643 Japanese

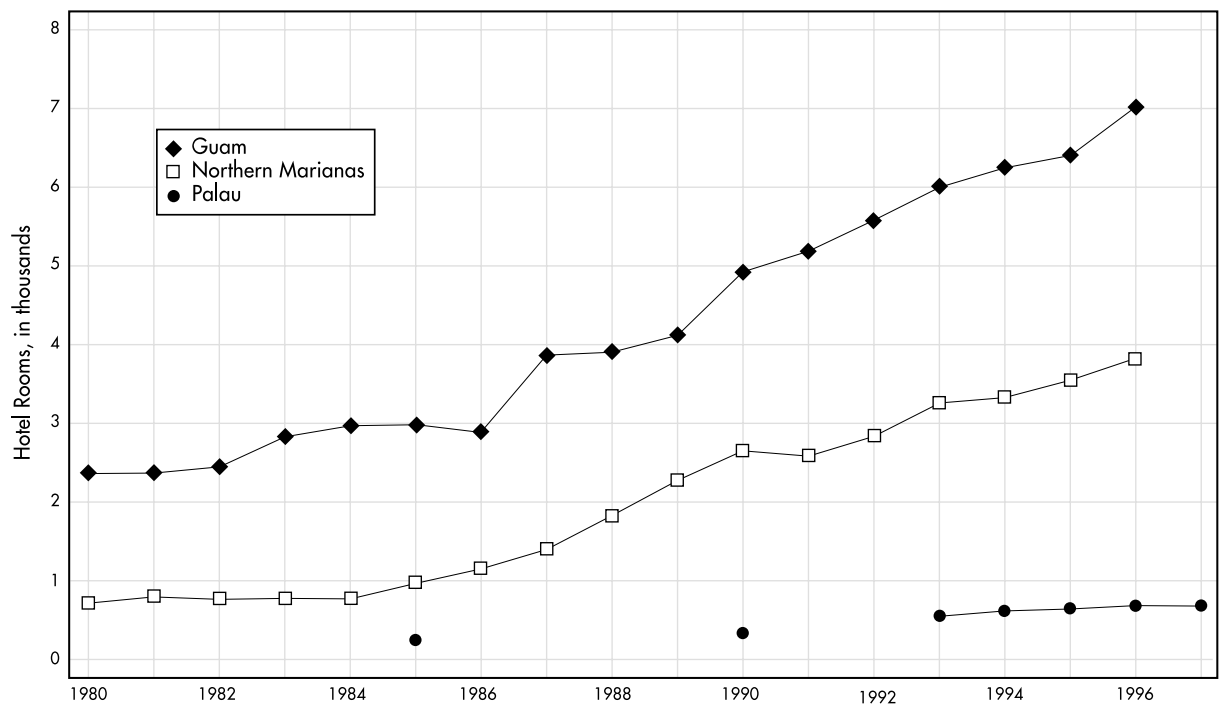

Figure 2. Growth in numbers of hotel rooms in Guam, Palau, and the Northern Marianas. (Sources: Guam Visitors Bureau; CNMI Visitors Bureau; Palau Visitors Authority.) 
tourists who came to Guam, and the 345,97 I who came to the Northern Mariana Islands, in 1993 were brought by tour-package wholesalers based in Japan. Travel arrangements in the Mariana Islands were handled by tour companies with offices on Guam and Saipan, most of them subsidiaries of the major tour wholesalers" (Jackson I994, 20). A companion article in the same issue commented that "the Japanese segment of the tourism industry is very integrated, with little opportunity for local businesses to participate," and detailed the situation with a company-by-company analysis of business ties (Russel I994, I2).

Although Japanese interests had effectively "locked up" the business of Japanese tourism on Guam and Saipan, the "lock" was not exclusively that of the majors. A number of smaller Japanese wholesalers specializing in Guam and Micronesia were able to carve a niche in the industry, in part because of the long period of gestation prior to the expansion of air capacity from Japan to Guam and Saipan, as well as the absence of existing large, international-class hotels. Further, Air Micronesia, a "nonincumbent" under the bilateral aviation regime, claimed a large share of the air capacity in the region. Smaller Japanese agencies with business ties to Air Micronesia and specializing in travel services in the region were able to carve out a viable niche prior to the arrival of the majors, especially in the less popular destinations. Even in Guam, where mass Japanese tourism emerged first and unfolded on the largest scale, firms like R\&C Tours (which has close ties to Air Micronesia) and RIC Tours continue to compete head-to-head with mega-wholesalers like Japan Travel Bureau.

The control over access to tourism resources established by Japanese travel agency networks in Guam and Saipan also had implications for the "latecomer" tourists from Taiwan and South Korea, whose number began to grow significantly during the I990s. In a manner that parallels how Japanese travel firms were confronted with preexisting non-Japanese hotel interests in major global travel destinations, Korean and Taiwanese travel firms were confronted with a market in which key resources were controlled by outside interests. Their business is welcomed when there are rooms to be filled, but during peak periods when rooms are scarce the Korean and Taiwanese firms are at a decided disadvantage. This situation probably explains the larger share accounted for by Korean tourists in the secondary destination of Saipan. A further case in point occurred during the particularly tight Chinese New Year period of 1994, when Taiwanese tourists were effectively locked out of the most desirable hotels (Galang I995). Although the details are somewhat hazy, the experience might have served as a catalyst for the redirection of travelers to Palau. 


\section{International Tourism in Palau}

The perceived promise of tourism as an engine of the Palauan economy may be understood by looking at recent trends in foreign tourism there. Although the market is rather small (73,719 visitor arrivals in 1997), growth has been impressive in recent years, and what seems like a tiny drop in the tourism bucket elsewhere goes far in a country with 17,000 residents. The number of visitor arrivals grew by an annual average of $\mathrm{I} 2$ percent during the first half of the I990s (Khalegi I996, 4). According to a Bank of Hawaii study, tourist spending as measured by receipts of local vendors increased 4I.6 percent from I99I to I993, from $\$$ I 2.5 million to \$17.7 million. For the period I994 to I996, the figures were \$27.5 million to $\$ 67.9$ million, for an increase of I47 percent (Bank of Hawaii I997c, 2I). Another source estimated that export income earned from tourism in I996 was $\$ 46.8$ million, or about 8I percent of total export income (Palau Office of Planning and Statistics, nd). Moreover, this rapid growth in tourism occurred in a context where the shares of key sectors such as agriculture, fisheries, and public administration were declining steadily. Tourist spending increased its share of Palau's total gross domestic product from I 4.9 percent to 23.3 percent from I99I to I993, and from 31.0 percent to 46.0 percent from I994 to 1996 (Bank of Hawaii, I997c, 2I).

Palau is currently the third largest visitor destination in the Micronesian region in terms of the total number of visitors annually (table I). There is also an extremely large gap, along the lines of an order of magnitude, between Palau's figures and those of second-ranked Saipan. The reasons for Palau's "distant third" status are implicit in the preceding discussion, but it is helpful to treat them more directly here in order to flesh out future scenarios for tourism development there.

A certain historical inevitability about Guam's emergence as Micronesia's largest tourist destination in the last quarter century was not duplicated in Saipan and Palau. As the area's largest island, Guam possessed some natural advantages for tourism development, but probably more decisive factors were its designation as a port of entry into the United States in the bilateral Japan-US aviation treaty and its status as a US territory. Tourists were channeled from the growing Japanese market to Guam, and the relatively open and uncomplicated American legal framework for foreign investment facilitated the construction of a "tourist-class" infrastructure. The two factors worked synergistically to spur Guam's emergence as the aviation and tourism hub of the Micronesian region. 
The number two status of Saipan, which like Palau was part of the Trust Territory, was less of a given and serves to highlight the role of political and economic variables in shaping Palau's situation. Palau's physical attributes are certainly no less attractive for tourism than Saipan's, and Palau possesses a slight advantage insofar as Babeldaob, the second largest landmass in Micronesia, offers a much larger area for tourism development. Palau is also less prone to the typhoons that regularly disrupt tourist flows and cause physical damage in Guam and Saipan. Furthermore, as occasional group visits by wartime veterans and former Japanese residents of Palau indicate, Palau's status as the former capital of the Japanese South Sea territory gives it a potential edge as a cultural and historical destination for East Asia's largest overseas tourist market. Although Saipan is closer to Japan, the difference in terms of direct flight time is relatively small and is often negated for the large number of tourists who stop over in Hagatna.

Saipan's status relative to Palau is most convincingly explained by the "political" factors of its designation as a port of entry in the Japan-US aviation treaty and its early negotiation of commonwealth status rather than its "natural" attributes. Thanks to the bilateral treaty, by the I970s both Japanese and American airlines could fly directly to Saipan from Japan, while Palau was restricted to indirect access on a spur route monopolized by a single American airline. In addition, by resolving key uncertainties of political status and giving the appearance of a resolution of land tenure issues, Saipan's early achievement of commonwealth status tended to reassure would-be investors in tourism development projects. By contrast, during this period Palau was embroiled in a long and bitter conflict over its future political status that was not conducive to similar investment projects. Under these circumstances, it is hardly surprising that Palau's development as an international tourism destination lagged behind Saipan's.

Like that of other areas in the former Trust Territory, Palau's initial development as a tourist destination was closely tied to the policies and fortunes of Air Micronesia. Regularly scheduled air service to Palau was initiated in the late I960s along with the rest of the airline's Trust Territory service. However, Palau did not lie on Air Micronesia's trunk route from Honolulu to Hagatna. As in other parts of the territory, Palau's first "tourist" hotel, the 56-room, \$2.I8 million Palau Continental Hotel in Koror, was built as part of the development agreement that Air Micronesia signed in order to gain US government approval to operate in the region. While similar in scale to the one built by Continental in Chuuk, 
the hotel was considerably smaller than those built in Saipan ( 184 rooms) and Guam (200 rooms) (Kelley and Penseyres I976, I I). Various schemes were advanced by local Micronesian interests in the ensuing years for further major hotel developments in Palau, but none bore fruit.

In the meantime, the number of Japanese overseas travelers began to increase conspicuously, and Japanese businesses began to take an interest in tourism development in Palau as a supplementary destination to the core attractions of Guam. The first major indicator of this interest was Japan Airlines' purchase in I98I of the Palau Continental, which was renamed the Hotel Nikko Palau. However, the first major jump in Palau's tourist-class hotel capacity did not occur until the opening of the rooroom Palau Pacific Resort complex in I985, which nearly tripled the country's capacity in its class. The project was initiated by one of Japan's leading real estate developers, the Tokyu Land Corporation. The project differed from the earlier Continental project in that it was built, as its name implies, as a more or less self-contained luxury beach resort away from downtown Koror. Personal interest on the part of Tokyu's president apparently had as much to do with the project's initiation and completion as nuts-and-bolts business calculations. Despite the Japanese connection, the hotel was not built to service Japanese guests exclusively, since according to its public relations manager only 60 percent of its guests were expected to be Japanese. Western expatriates in Asia were a major target for the non-Japanese segment of the projected clientele (Link 1985). In terms of its corporate structure, the Palau Pacific Resort was placed in the more internationalized Pan Pacific group of hotels rather than in the domestically based Tokyu Group's main line of hotels, a fact consistent with this reading.

The logistics and economics of air travel and accommodation as they have developed in Palau have given Japanese tourists there a different profile from those who visit Guam and Saipan. At the economic end of the picture, the need for travelers to change planes in Hagatna added to the time and expense associated with a tour package. Whereas during the winter of 1997 a typical tour to Guam or Saipan was a four-day package priced at between 40,000 and 60,000 yen, the counterpart for Palau was five days for a minimum of 80,000 to I 20,000 yen, causing it to straddle the I००,০০০-yen line used in the industry to distinguish "affordable" packages from premium ones. Thus, other things being equal, Japanese visitors to Palau would tend to be more wealthy and have more free time than their compatriots visiting Guam or Saipan. The relative absence of 
shops featuring designer-label merchandise and the large stage shows and nightclubs that are the staples of Japanese tourism in Guam and Saipan meant that the typical Japanese visitor to Palau was seeking something different, such as diving or a change from the hustle and bustle of Japanese urban life. In a nutshell, in Guam the Japanese visitor profile is that of a low-cost, "mass-market tourist," while in Palau it is that of a premium "niche-market tourist."

Palau's secondary status within the overall framework of the Japanese overseas travel industry is also reflected in how the business aspects of Japanese tour services are organized. In contrast to the situation in Guam and Saipan, none of the leading travel agencies directly administers branches in Palau, and tour operations are generally owned and handled by Palauans with Japanese connections. In this respect Palau is free from the "spider's web" of tight business connections among firms that handle Japanese tourists that local operators in Guam complain about. Nonetheless, the timing of the Palau Pacific Resort's opening allowed it to take nearly exclusive advantage of the boom in Japanese overseas travel that occurred in the mid-I980s. With little competition and with steady access provided by Continental Micronesia, the hotel did well enough to expand its capacity to I60 rooms in I994. At the same time, however, the scale of Japanese tourism in Palau has been modest enough that the "majors" of the Japanese industry have not found it in their interest to establish direct operations.

A new element was introduced into the Palauan international tourism picture in 1995. As detailed by Eric Harwit, Taiwan's willingness to offer business and investment in exchange for support in its diplomatic competition with mainland China dovetailed with Palau's new political status to create a rapidly expanding Taiwan-based tourism. In exchange for Palau's waiving of the complicated visa acquisition procedures that Taiwanese travelers are forced to endure in most countries, Taiwanese business and government interests arranged for regular air service between the two countries (Harwit, this issue). Along with the air service came a number of new Taiwan-financed tourism-related development projects in Palau, the most prominent of which is the recently completed Palasia Hotel in downtown Koror.

Since 1995 Taiwanese tourism in Palau has taken on many of the characteristics of mass market tourism. The most fundamental reason for this is the distinctive way in which Taiwan's diplomatic situation and relative lateness as a tourist exporting country intersected with the economics of 
air travel in the context of Palau's relative "underdevelopment" as a tourist destination. The options available to Taiwan citizens for a "quick getaway" vacation were limited by the difficulty of obtaining visas. On top of this, the preemption of prime hotel facilities by the large, wellheeled Japanese travel agencies meant that Taiwanese visitors were often "squeezed out" of desirable resorts. Thus, when Palau opened its market to visitors from Taiwan in I995, it was tapping into a pent-up demand. On top of this, the initiation of regular air services from Taiwan to Palau, which initially included Continental Micronesia, in addition to Taiwan's Far Eastern Air Transport, meant that a large number of seats now needed to be filled on a regular basis-40,000 or so annually according to one study (Harwit, this issue). While these flights are filled to capacity during peak season, off-peak load factors (that is, passengers divided by capacity) at times fall below 50 percent. The severe imbalance between capacity and demand creates pressure on travel agencies and tour operators who buy seats from the airline in blocks for an entire season, to offer tours at low prices and to make up lost revenue at the destination. In contrast to destinations with a large stock of "tourist-class" hotel operators with whom to share these cost pressures, Palau offers the tour operators relatively little room to attract customers by offering discounts on rooms in normally expensive hotels. The result is that tour operators' efforts to recoup lost revenues tend to take the form of demands on local restaurants, shops, and other local businesses involved in the industry to offer steep discounts, rebates, and other "incentives."

Under these circumstances it is not surprising that complaints about these practices by Taiwanese tour operators are widely heard in Palau. The rapid growth of tourism in Palau has caused other problems as well. The most recognized has been the damage to the ecosystem. Stories circulate widely about fan and other forms of coral being trampled by nonswimming groups of tourists, and others catching and eating Palau's famous freshwater jellyfish. Visible at the previously pristine beaches are evidence of increased runoff, a compacting of sand, litter, and other environmental disruptions. Equally significant has been the increased strain on the country's limited infrastructure due to increases in demand for water and power, as well as perceived social disruption. Also discussed in this regard has been a dramatic increase in the number of foreign workers as the demand for labor has outstripped the supply of Palauans willing to work in tourism-related industries. On the business side, people have complained that the industry is not contributing all that it should to 
the local economy. According to estimates by the Palau Visitors Authority, 85 percent of tourism revenues are being pocketed by foreign operators and suppliers, many of whom also escape payment of various taxes and fees through the use of "front" businesses registered in the name of a Palauan owner but controlled by foreign interests. The authority estimates that only I 5 percent of tourism revenues remain in Palau, which in absolute terms amounts to a mere \$250 per Palauan (PVA I997, I3).

\section{Concluding Remarks}

The essence of the economic challenge facing Palau as understood by the local community has been succinctly expressed in a recent government development plan:

Palau has few resources to offer the rest of the world in order to support its desired lifestyle and enhance its culture and environment. However, those which it has-a unique and fascinating array of reefs, water and islands-are in diminishing supply and are located adjacent to the world's fastest growing areas of demand. Necessity and proximity now combine to possibly threaten the fragile culture and ecosystem of Palau. The challenge to decision makers is to open up good quality tourism facilities to an increasing number of investors and visitors without causing intolerable damage to the attractions and Palau social system. (Palau I994, 2:I69)

A distinctive feature of the discourse about tourism development in Palau is the frequent contrasting of desirable "up-market" tourism with undesirable "mass-market" tourism, which is viewed as the primary source of the various negative consequences being generated by the increasing numbers of tourists:

Budget [mass-market] travelers frequently have a greater impact on the social and cultural environment than the quality/experienced [ie, up-market] travelers. They arrive in large numbers and have a cumulative effect on the resources. They are often first time international travelers and may demonstrate immature and unwanted behavior-loud, intrusive, demanding and disrespectful of the local environment. These qualities are exhibited by most travelers from any country who have not had the experience to establish a conscientious travel ethic.

Mass travel is also tightly controlled by the country of origin. Margins are very thin and therefore it is critical that the tour operators/wholesalers who package this market have vertically integrated travel products that enable small profit from each component of the product. This frequently excludes a 
significant participation of the local ground operators and suppliers. (PVA I997, I4)

According to this line of thought, mass-market tourism does not simply generate problems of its own, but is also a positive threat to desirable, upscale tourism: "The mass market is already half the volume to Palau and within the next three years will outnumber the quality small/group Foreign Independent Traveler (FIT) market by two to one. This is a tenuous situation which could result in the eventual elimination of the high end market who will readily shift to other destinations for the experience they enjoyed in Palau five to ten years ago" (PVA I997, I4).

In this paper I have examined the historical and regional context of tourism in Palau with an emphasis on the associated political economy of interstate tourism. Various forces have worked to make Palau a secondary, niche market within the larger pattern of tourism flows in the Micronesian region, but with an incipient mass-market element (Taiwanese tourism), also profoundly shaped by politics. Among these various elements the pattern of air route allocation produced by the earlier trust territory status of Micronesia and the bilateral US-Japan aviation treaty played a fundamental role. The gaining of Palauan independence in 1994, and with it direct national control over air traffic into and out of Palau, established the potential for reshaping the parameters of Palauan tourism on radically different terms.

Palau has already seen some of the consequences of mass tourism in its experience with Taiwan tourists. Depending on how tourism development unfolds, a mass-oriented Japanese tourism based on cut-rate packages marketed by the big travel agencies is a possible future scenario. The construction of a paved road around the entire island of Babeldaob is underway and it is widely anticipated that this will lead to major investments in tourism facilities, including new golf courses and hotels. Furthermore, political independence means that Palau is no longer bound by the provisions of the bilateral aviation arrangements based on the Japan-US aviation treaty and is free to negotiate flights directly with Japan and other countries. Regularly scheduled direct charter flights now fly between Japan and Palau. Discussions are under way for the creation of a Japanfinanced Palauan national carrier that would presumably service routes to and from Japan. In the past, the limited seats, poor connections, small number of hotel rooms, and limited variety of available leisure activities meant that tourism in Palau was not on a scale sufficient to induce the 
big Japanese travel interests to establish direct operations. However, the development of Babeldaob could conceivably push Palau over the threshold, leading very rapidly to precisely the kind of mass-market development and oligopolization that the country is ostensibly seeking to avoid.

In its Sustainable Development Plan, the Palau Visitors Authority has outlined a path of tourism development focused on ecotourism and cultural tourism as a way to minimize environmental damage, further national identity, keep a greater share of tourism revenues in Palau, and avoid foreign domination of the industry both in terms of ownership and the workforce (I997). The plan would involve measures to increase local participation, providing appropriate training and assistance to Palauans entering the tourism industry. It would also attempt to control the growth of the industry and redirect it to provide opportunities more suited to Palauan sensibilities. It would involve strict regulation of tourism activities in order to forestall environmental damage to land and marine resources and the training of both locals and visitors for a more ecologically friendly interaction with the natural environment.

If successfully implemented, such a strict, nationalistic approach to tourism development would undoubtedly limit the attractiveness of Palau as a site for foreign investment, potentially depriving Palau of the capital it needs to sustain the development of the industry as its compact moneys run dry. This cost may have to be borne if the vision of tourism development laid out in the plan is to be attained, although in the long run the success of such a strategy will no doubt enhance the viability and value of Palau as a destination in its desired market. One issue that deserves exploration as a way of alleviating potential capital shortfalls is whether or not Japanese overseas development assistance can be used to advance the sustainable tourism envisioned. Japan, after all, has pursued an increased diplomatic presence while emphasizing its ostensible commitment to ecological values and cultural sensitivity in its relations with the Pacific Islands region (Urabe 1996; Finin and Wesley-Smith 1997). Effective internal governance and tremendous diplomatic skill will clearly be required if current sustainable tourism plans are to succeed in Palau.

\section{References}

Ahmed, Zafar, and Chon Kye-Sung

I994 Marketing the United States to Korean Travelers. Cornell Hotel and Restaurant Administration Quarterly 35 (2): 90-94. 
Bank of Hawaii

I997a Commonwealth of the Northern Mariana Islands Economic Report. Honolulu: Bank of Hawaii.

I997b Guam Economic Report. Honolulu: Bank of Hawaii.

I997c Republic of Palau Economic Report. Honolulu: Bank of Hawaii.

Carlile, Lonny

I996 Economic Development and the Evolution of Japanese Overseas Tourism, I964-I994. Tourism Recreation Research 2I (I): I I-I8.

Choy, Dexter J L

I988 Pacific Asia: The Mass Market in Travel. Cornell Hotel and Restaurant Administration Quarterly 28 (4): 82-88.

Connell, John

I99I Island Microstates: The Mirage of Development. The Contemporary Pacific 3:25I-287.

Davies, R E G

I984 Continental Airlines: The First Fifty Years, I 934-I984. Woodlands, TX: Pioneer Publications.

Doty, Laurence

I977a Saipan Authority Clouds Japanese Bilateral Talks. Aviation Week and Space Technology I07 (30 May): 27-28.

I977b US Holds Firm on Japanese Bilateral. Aviation Week and Space Technology 107 (25 July): 38.

Finin, Gerard A, and Terence Wesley-Smith

I997 A New Era for Japan and the Pacific Islands: The Tokyo Summit. AsiaPacific Issues, 32. Honolulu: East-West Center.

Forsyth, Peter, and John King

I996 Cooperation, Competition, and Financial Performance in South Pacific Aviation. In Flying High: Civil Aviation in the Asia Pacific, edited by Gary Clyde Hufbauer and Christopher Findlay, 99-I I6. Washington, DC: Institute for International Economics.

Galang, Jerry

I995 What Happened to the Taiwan Tourists? Guam Business News I3 (7): 32-40.

Guam Business News. Hagatna. Monthly.

GVB, Guam Visitors Bureau

I998 Internal statistical reports provided to author.

Hezel, Francis X

1995 Strangers in Their Own Land: A Century of Colonial Rule in the Caroline and Marshall Islands. Pacific Islands Monograph Series, I3. Honolulu: Center for Pacific Islands Studies and University of Hawai i $\mathrm{i}$ Press. 
Huang Chun-Te, Chi-yeh Yung, and Jen-Hung Huang

I996 Trends in Outbound Tourism from Taiwan. Tourism Management (May): 223-228.

Isozaki, Mark Akira

I993 The Tour Wholesaler's Role in the Japanese Travel Distribution System. Master's thesis. School of Travel Industry Management, University of Hawai'i at Mānoa.

Jackson, Christine J

I994 The Spider Web. Guam Business News I2 (4): 20-24.

Jaggi, Gautam, and Gena Morgan

I996 Recent Civil Aviation Experience. In Flying High: Civil Aviation in the Asia Pacific, edited by Gary Clyde Hufbauer and Christopher Findlay, I 37-2 I 2. Washington, DC: Institute for International Economics.

Kelley, Lane, and Marjorie Penseyres

I976 Continental Airlines and the Development of Tourism in the Marianas, TTPI. Mimeograph, University of Hawai'i at Mānoa.

Khalegi, Hossein

1996 An Analysis of Tourism Activities in Palau. Pacific Business Center Program Paper. Koror: Palau Visitors Authority.

Kojima Ikuo I995 Toraberu. Tokyo: Niki shuppan.

Korea Travel News. Seoul. Monthly. I989 Turning Point for Korean Tourism. Release I3 (January): I-2.

La Croix, Sumner, and David Jonathan Wolf

I995 The Asia-Pacific Airline Industry: Economic Boom and Political Conflict. East-West Center Special Reports, 4. Honolulu: East-West Center.

Link, Dave

I98 5 Big-Time Tourism Comes to Palau. Guam Business News 3 (4): 26-27. Nero, Karen

I989 Time of Famine, Time of Transformation: Hell in the Pacific, Palau. In The Pacific Theater: Island Representations of World War II, edited by Geoffrey M White and Lamont Lindstrom, II7-I47. Pacific Islands Monograph Series, 8. Honolulu: Center for Pacific Islands Studies and University of Hawai'i Press.

Nozawa Hiroko

I992 A Marketing Analysis of Japanese Outbound Travel. Tourism Management $\mathrm{I} 3: 226-234$.

Nygard, Stephen V

I984 Pulling Tourism's Strings. Guam Business News 2 (9): I I-20.

Palau, Republic of

I994 Economic Development Plan: Fiscal Years 1995-I999. Two volumes. Koror: Government of Palau. 
PATA, Pacific Area Travel Association

I993 Palau: Your Future in Tourism. Woolloomooloo, Nsw: PATA.

PIM, Pacific Islands Monthly

I977 Micronesia: A "Pawn" in the Air War between US and Japan. Pacific Islands Monthly, June, 63-64.

PVA, Palau Visitors Authority I997 Sustainable Development Policies and Action Plan: Palau. Koror: PVA. Russel, Alison

I994 Dis-Integrating Tourism. Guam Business News I 2 (4): IO-I 8.

Travel Journal

I994 The kaigai ryoko sanjunen (1964-1994). Special issue of Travel Journal 3 I (36). (Tokyo weekly in Japanese.)

Urabe, Kazuyoshi

I996 Taiheiyo tosho koku gaiko no shin tenkai: nihon e no atsuki kitai [New developments in diplomacy toward small Pacific Islands nations]. Gaiko Forum [Foreign Policy Forum] 9 (3): 19-25. (Tokyo monthly in Japanese.)

Yajima, Katsumi

I997 Intavuu: Tsuaa operetaa wa ryoko sozai no tehainin. Travel Journal $34(3): 48-49$.

Yamauchi, Hirotaka, and Takatoshi Ito

I996 Air Transport Policy in Japan. In Flying High: Civil Aviation in the Asia Pacific, edited by Gary Clyde Hufbauer and Christopher Findlay, 33-6r. Washington, DC: Institute for International Economics. 